\title{
PD-1/PD-L1 in Cancer: Pathophysiological, Diagnostic and Therapeutic Aspects
}

\author{
Enrico Munari ${ }^{1,+}{ }^{+}$, Francesca R. Mariotti ${ }^{2,+}{ }^{\oplus}$, Linda Quatrini ${ }^{2}$, Pietro Bertoglio ${ }^{3}{ }^{\circ}$, Nicola Tumino ${ }^{2}$, Paola Vacca ${ }^{2}$, \\ Albino Eccher ${ }^{4}{ }^{\circ}$, Francesco Ciompi ${ }^{5}$, Matteo Brunelli ${ }^{6}$, Guido Martignoni ${ }^{6,7}$, Giuseppe Bogina ${ }^{8, \ddagger}$ and \\ Lorenzo Moretta $2, *, \ddagger$
}

Citation: Munari, E.; Mariotti, F.R.; Quatrini, L.; Bertoglio, P.; Tumino, N.; Vacca, P.; Eccher, A.; Ciompi, F.; Brunelli, M.; Martignoni, G.; et al. PD-1/PD-L1 in Cancer:

Pathophysiological, Diagnostic and Therapeutic Aspects. Int. J. Mol. Sci. 2021, 22, 5123. https://doi.org/ $10.3390 /$ ijms 22105123

Academic Editors: Nagaja Capitani, Cosima T. Baldari and Silvano Sozzani

Received: 31 March 2021

Accepted: 27 April 2021

Published: 12 May 2021

Publisher's Note: MDPI stays neutral with regard to jurisdictional claims in published maps and institutional affiliations.

Copyright: (c) 2021 by the authors. Licensee MDPI, Basel, Switzerland. This article is an open access article distributed under the terms and conditions of the Creative Commons Attribution (CC BY) license (https:// creativecommons.org/licenses/by/ $4.0 /)$.
1 Pathology Unit, Department of Molecular and Translational Medicine, University of Brescia, 25100 Brescia, Italy; enrico.munari@unibs.it

2 Immunology Area, Bambino Gesù Children's Hospital, IRCCS, 00146 Rome, Italy; fromana.mariotti@opbg.net (F.R.M.); quatrini.linda@opbg.net (L.Q.); tumino.nicola@opbg.net (N.T.); vacca.paola@opbg.net (P.V.)

3 Division of Thoracic Surgery, IRCCS Maggiore Teaching Hospital and Sant'Orsola University Hospital, 40133 Bologna, Italy; pieberto@hotmail.com

4 Pathology Unit, University and Hospital Trust of Verona, 37134 Verona, Italy; albino.eccher@aovr.veneto.it

5 Computational Pathology Group, Department of Pathology, Radboud University Medical Center, 6543 SH Nijmegen, The Netherlands; f.ciompi@gmail.com

6 Department of Diagnostics and Public Health, University of Verona, 37134 Verona, Italy; matteo.brunelli@univr.it (M.B.); guido.martignoni@univr.it (G.M.)

7 Pathology Unit, Pederzoli Hospital, 37019 Peschiera del Garda, Italy

8 Pathology Unit, IRCCS Sacro Cuore Don Calabria, 37024 Negrar di Valpolicella, Italy; giuseppe.bogina@sacrocuore.it

* Correspondence: lorenzo.moretta@opbg.net

+ Equally contributed.

$\ddagger$ Share the senior authorship.

\begin{abstract}
Immune evasion is a key strategy adopted by tumor cells to escape the immune system while promoting their survival and metastatic spreading. Indeed, several mechanisms have been developed by tumors to inhibit immune responses. PD-1 is a cell surface inhibitory receptor, which plays a major physiological role in the maintenance of peripheral tolerance. In pathological conditions, activation of the PD-1/PD-Ls signaling pathway may block immune cell activation, a mechanism exploited by tumor cells to evade the antitumor immune control. Targeting the PD-1/PD-L1 axis has represented a major breakthrough in cancer treatment. Indeed, the success of PD-1 blockade immunotherapies represents an unprecedented success in the treatment of different cancer types. To improve the therapeutic efficacy, a deeper understanding of the mechanisms regulating PD-1 expression and signaling in the tumor context is required. We provide an overview of the current knowledge of PD-1 expression on both tumor-infiltrating T and NK cells, summarizing the recent evidence on the stimuli regulating its expression. We also highlight perspectives and limitations of the role of PD-L1 expression as a predictive marker, discuss well-established and novel potential approaches to improve patient selection and clinical outcome and summarize current indications for anti-PD1/PD-L1 immunotherapy.
\end{abstract}

Keywords: NK cells; PD-1; PD-L1; glucocorticoids; immunotherapy; cancer

\section{Introduction}

Programmed cell death protein 1 (PD-1) was initially discovered as an apoptosisassociated gene during $\mathrm{T}$ cell thymic selection. It was shown to be involved in the regulation of the immune response and is considered one of the most important inhibitory checkpoints [1-4]. PD-1 belongs to the CD28/cytotoxic T-lymphocyte-associated protein 4 (CTLA-4) subfamily of the immunoglobulin (Ig) superfamily [5] and is expressed on T, B, myeloid and Natural Killer (NK) cells [6,7]. PD-1 specifically interacts with programmed 
death ligand 1 (PD-L1) and programmed death ligand 2 (PD-L2). Of note, PD-L1 is expressed in both hematopoietic and non-hematopoietic cells and on antigen-presenting cells (APC), while PD-L2 is found, upon cell activation, on macrophages and dendritic cells [8-10]. The binding of PD-1 to its ligands impairs T cell receptor (TCR) signaling T cell activation.

The level of PD-1 expression on T cells is related to the strength of TCR signaling. Its physiological role is to counteract excessive $\mathrm{T}$ cell activation while it returns to basal levels after the antigen has been cleared. However, the persistence of antigen stimulation, occurring in both chronic viral infection and cancer, may determine a constitutive PD-1 cell surface expression leading to the inhibition of immune response and impaired $\mathrm{T}$ cell function. In this context, due both to the tumor immunosuppressive environment and to prolonged exposure to tumor antigens, high PD-1 expression may be detected on tumorinfiltrating lymphocytes (TILs), which is associated with defects in immune cell function and the expression of other inhibitory receptors [11,12]. Therefore, it is conceivable that this mechanism has been "stolen" by tumor cells to favor peripheral tolerance and escape the antitumor immune response. In this context, the expression of PD-1 ligands has been frequently detected in different tumors, such as neuroblastoma (NB), melanoma, lung and gastric cancers. It appears that the stimuli present in the tumor microenvironment (TME) promote the expression of these PD-1 ligands [13-15]. In vivo studies revealed that the inhibition of the PD-1/PD-Ls axis could restore immune cell function, thus providing a promising strategy for immunotherapy [16]. Indeed, the use of anti-PD-1 and anti-PD-L1 monoclonal antibodies (mAbs), in view of particularly encouraging results in patients with lung or melanoma, have been approved by the Food and Drug Administration (FDA) $[17,18]$ (see paragraph 5.0). In this review, we highlight the recent findings on PD-1 expression on both NK and T cells in the tumor context. In addition, we provide an overview of the different diagnostic approaches to improve patient selection and the therapeutic strategies to target the PD-1/PD-L1 axis alone or in combination therapies in several adult and pediatric cancers.

\section{PD-1 Expression in Antitumor Effector T and NK Cells}

Investigating PD-1 expression in TILs is essential in order to better identify mechanisms adopted by tumor cells to evade the control by the immune system and to develop more efficient therapies.

Of note, immune infiltrates may contain not only $\mathrm{T}$ but also NK cells. T cells, after encountering tumor antigens in tumor-draining lymph nodes, acquire effector function and migrate to the tumor site to promote tumor eradication [19]. However, once at the tumor site, $\mathrm{CD}^{+}$effector $\mathrm{T}$ cells have to overcome the inhibitory signals present in the TME. A number of studies demonstrated that $\mathrm{CD}^{+} \mathrm{T}$ cells lose their effector function during tumor progression, an effect mainly related to inhibitory checkpoint expression [20-22]. Of note, both $\mathrm{CD} 4^{+} \mathrm{PD}-1^{+}$and $\mathrm{CD} 8^{+} \mathrm{PD}-1^{+} \mathrm{T}$ cells have been detected in different tumors, including head and neck, gastric, breast and lung cancers, melanoma and hepatocellular carcinoma (Table 1) $[11,12,23-26]$. Kumagai and colleagues analyzed the CD8 ${ }^{+} \mathrm{PD}-1^{+}$subpopulation in non-small cell lung cancer (NSCLC), gastric cancer (GC) and malignant melanoma (MM) treated with $\mathrm{mAb}$ therapy. They showed that higher PD-1 expression on $\mathrm{CD} 8^{+} \mathrm{TILs}$ reflects the interaction with tumor antigens and can be considered a predictive biomarker for delivering therapeutic antibodies able to disrupt the PD-1/PD-L1 interaction [27]. These authors also detected high numbers of PD- $1^{+} \mathrm{CD} 8^{+} \mathrm{T}$ cells in the TME of responders as compared to non-responder patients. In particular, in both murine models and human samples, a lower expression of PD-1 on regulatory T cells (Treg) and a higher PD-1 expression on $\mathrm{CD}^{+} \mathrm{T}$ cells correlate with a favorable antitumor efficacy of mAb treatment. In NSCLC, the frequency of PD-1 CD8 ${ }^{+}$TILs located in proximity to neoplastic cells is inversely correlated with NSCLC clinical staging [28]. PD-1 expression has also been detected on CD4 ${ }^{+} \mathrm{T}$ cells in the TME of Hodgkin lymphomas and follicular lymphomas, suggesting their role in the PD-1-induced blockade of antitumor immunity [29,30]. Li et al. analyzed the expression of 
inhibitory checkpoints in peripheral blood (PB) T cells in comparison to TILs in a cohort of primary and treatment-naïve patients with different tumors and found a higher PD-1 ${ }^{+}$ cell frequency in TILs as compared to T cells from PB [31]. These results are in line with previous studies in lung, liver, esophageal and breast cancers showing that the percentage of PD- $1^{+} \mathrm{CD}^{+}$cells present in $\mathrm{PB}$ and at the tumor site may be considered as a prognostic marker for response to $\mathrm{mAb}$ immunotherapy [32-35].

Of note, clear evidence of PD-1 expression on NK cells has recently emerged (Table 1). Under physiological conditions, different from T cells, PD-1 expression in NK cells is restricted to a subset of fully mature, circulating cells in cytomegalovirus (CMV)-seropositive, otherwise healthy individuals and is maintained stable over time [7]. Several studies revealed the presence of $\mathrm{PD}-1^{+} \mathrm{NK}$ cells in the $\mathrm{PB}$ of patients with multiple myeloma and digestive cancers [36,37]. The presence of PD- $1^{+} \mathrm{NK}$ cells was also detected in CD56 dim and CD56 ${ }^{\text {bright }}$ NK cell subsets in Kaposi sarcoma and Hodgkin lymphoma patients, respectively $[38,39]$. Similarly, in the PB of renal cell carcinoma patients, PD-1 expression was restricted to a mature, cytolytic CD56 ${ }^{\mathrm{dim}} \mathrm{NK}$ subset and correlated with the stage of the disease [40]. Hsu et al. showed that in lymphoma mouse models, PD-1 is expressed on a discrete fraction of NK cells represented by the most activated and functionally responsive intratumoral NK population [41]. PD-1 engagement by PD-L1 ${ }^{+}$tumor cells suppresses NK cell-mediated cytotoxicity, while targeting of the PD-1/PD-L1 axis allows the reactivation of NK responses. The inhibition of NK cytotoxic function, mediated by PD-1, was also detected in PD- $1^{+}$NK cells identified in the peritoneal fluid of ovarian carcinoma patients, demonstrating a pivotal role of PD-1 in regulating the NK cell function [7]. The impaired expression of CD107a and release of perforin and granzyme B together with a weaker antitumor activity characterized the NK PD- $1^{+}$cells detected in the PB of lung cancer patients [42]. In addition, a recent study on NSCLC patients showed that tumor-infiltrating NK cells express PD-1, as well as other inhibitory checkpoints, and that their dysfunction correlates with increasing levels of membrane PD-1 expression [43]. Of note, PD-1 is expressed not only on NK cells but also on innate lymphoid cells (ILCs), a heterogeneous group of cells belonging to the lymphoid lineage that is classified, according to both the transcriptional factors required for development and their functions, in different groups (ILC1, ILC2, ILC3 and LTi-like) that mirror T cell counterparts and play a pivotal role in tissue repair and immune defense (Table 1). In particular, we demonstrated that ILC3 cells from pleural effusions of patients with primary or metastatic pleural tumors expressed functional PD-1 [44]. PD-1 expression has also been found on ILC2 and ILC3 in gastrointestinal tumors [45]. Despite the increasing information on PD-1, a better understanding of the mechanisms regulating its expression and signaling in NK and helper ILC cells in the tumor context is required in order to further improve the current therapeutic approaches aimed to unleash PD-1-dependent immune cell blockade [46]. In this context, a recent study shed some light on how the TME milieu could induce PD-1 expression on NK cells [47].

Table 1. Evidence reporting PD-1 expression on human T, NK and ILC cells in different cancers. For each data tumor type, cell subset and reference have been reported. PB: peripheral blood; PE: Plural effusion; TILs: tumor-infiltrating lymphocytes; DLBCL: diffuse large B-cell lymphoma; ADC: Adenocarcinoma; NSCLC: non small cell lung cancer; SCC: squamous cell carcinoma.

\begin{tabular}{|c|c|c|}
\hline Type of Tumors & Cell Subsets & References \\
\hline $\begin{array}{l}\text { Breast Cancer }(B C) \\
\text { Invasive ductal BC } \\
\text { Primary BC }\end{array}$ & $\begin{array}{l}\mathrm{CD}^{+} \text {TILs } \\
\mathrm{CD}^{+} \text {TILs }\end{array}$ & $\begin{array}{l}{[26]} \\
{[35]}\end{array}$ \\
\hline $\begin{array}{c}\text { Melanoma } \\
\text { Metastatic melanoma lesions } \\
\text { Metastatic melanoma } \\
\text { Malignant melanoma (MM) }\end{array}$ & $\begin{array}{c}\mathrm{CD}^{+}, \mathrm{CD}^{+} \mathrm{TILs} \\
\mathrm{CD} 8^{+} \text {TILs } \\
\text { CD8+ TILs }\end{array}$ & $\begin{array}{l}{[12]} \\
{[23]} \\
{[27]}\end{array}$ \\
\hline Follicular lymphoma (FL) & $\mathrm{CD}^{+}{ }^{+} \mathrm{TILs}$ & [30] \\
\hline
\end{tabular}


Table 1. Cont.

\begin{tabular}{|c|c|c|}
\hline Type of Tumors & Cell Subsets & References \\
\hline \multicolumn{3}{|l|}{ Hodgkin Lymphoma (HL) } \\
\hline Primary classical HL & CD4+ TILs & [29] \\
\hline HL and DLBCL & NK PB and Intratumoural & [39] \\
\hline Ovarian carcinoma & NK peritoneal fluid/ascites & [7] \\
\hline Karposi sarcoma & NK PB & [38] \\
\hline Renal cell carcinoma (RCC) & NK PB & [40] \\
\hline \multicolumn{3}{|l|}{ Lung cancers } \\
\hline Primary and metastatic & ILC3 PE & [44] \\
\hline \multirow{2}{*}{ Lung cancer and ADC } & NK PE & [47] \\
\hline & NK PB & [42] \\
\hline NSCLC (ADC and SCC) & $\mathrm{CD}^{+}$TILs & {$[28]$} \\
\hline Advanced and primary NSCLC & $\mathrm{CD}^{+}, \mathrm{CD}^{+}{ }^{+} \mathrm{TILs}$ & {$[27,32]$} \\
\hline NSCLC & NK Intratumoural & {$[43]$} \\
\hline \multicolumn{3}{|l|}{ Digestive Cancers } \\
\hline Gastric cancer & $\mathrm{CD}^{+}$TILs & [27] \\
\hline Gastrointestinal (oesophageal, gastric, colon, rectal tumors) & ILC2, ILC3, NK intratumoral & [45] \\
\hline \multirow[t]{2}{*}{ Hepatocellular carcinoma (HCC) } & $\mathrm{CD}^{+}$TILs & [25] \\
\hline & $\mathrm{CD}^{+}, \mathrm{CD}^{+} \mathrm{TILs}$ & [33] \\
\hline ESCC, HCC, colorectal cancer and biliary cancer & NK Intratumoural and PB & [37] \\
\hline Oesophageal cancer & $\mathrm{CD}^{+} \mathrm{CD}^{+} \mathrm{PB}$ and TILs & [34] \\
\hline Multiple Myeloma & NK PB & [36] \\
\hline
\end{tabular}

\section{Mechanisms of PD-1 Expression}

Since the interaction between PD-1 on T/NK effector cells and PD-L1 on tumor cells represents a major pathway for immune evasion, many studies have been conducted to identify the mechanisms responsible for the expression of this checkpoint. In a setting different from the tumor, it was demonstrated that endogenous glucocorticoids (GCs) in combination with the cytokines IL-15 and IL-18 induce PD-1 expression at the transcript level on murine splenic NK cells upon viral infection [48]. The requirement of GCs for the de novo PD-1 expression was also confirmed in human NK cells. Indeed, high levels of cortisol were detected in the pleural effusions from patients with lung cancer, associated with increased numbers of PD- $1^{+} \mathrm{NK}$ cells in the tumor microenvironment $[44,47]$. However, GCs alone were not sufficient, but inflammatory cytokines were also needed for PD-1 expression. Interestingly, in humans, NK cell stimulation with IL-12 was also required in addition to IL-15, IL18 and GCs. Moreover, in human NK cells, PD-1 expression was not only induced by GCs at the transcriptional level, but also at the post-transcriptional level [47]. Although in T cells GCs are not required for PD-1 expression, it was shown that they can further enhance it on both mouse and human T cells [49]. Accordingly, GCs potentiate the inhibitory effect of PD-1 on antigen-dependent $T$ cell activation [50]. Of note, GC treatment enhances not only PD-1 but also Tim3 and Lag3 expression in CD8 ${ }^{+}$ T lymphocytes, both in mouse and human settings, through GC receptor (GR)-mediated transactivation. The authors showed an increase in the expression of the gene encoding the GR in terminally dysfunctional tumor-infiltrating $\mathrm{T}$ cells, and the existence of a correlation between active GC signaling and failure to respond to the checkpoint blockade in both preclinical tumor models and melanoma patients [51]. Therefore, PD-1 induction on effector $\mathrm{T}$ and NK cells represents an additional mechanism of immune suppression exerted by GCs, suggesting that corticosteroid therapy may be counterproductive in combination with PD-1 immune checkpoint blockade in patients with cancer. Recently, in a retrospective study, the impact of systemic corticosteroids in combination with immune checkpoint inhibitors (ICIs) was investigated to address this issue. It was concluded that GC use for an application other than immune-related adverse effects (irAE) has a negative impact on 
overall survival and response to ICIs, while GC therapy for irAE does not significantly affect response to immunotherapy [52].

\section{Applications of PD-L1 Immunohistochemistry}

The selection of patients who may benefit the most from anti-PD-1/PD-L1 therapies is a challenging issue, since a relevant percentage of patients do not respond to these treatments [53-55]. For this reason, much effort has been made to develop biomarkers with predictive potential. The best known and most used biomarker to date is PD-L1 expression, detected by immunohistochemistry, on tumor cells and/or immune cells. Multiple assays designed to assess PD-L1 expression have been developed in parallel with different antibodies targeting the PD1/PD-L1 axis. However, not all assays have the same level of interchangeability, and analysis on the same samples can lead to different results, with important implications for patient eligibility for treatment with anti-PD1/PD-L1 antibodies.

Three of the FDA-approved assays are classified as companion diagnostics, meaning that they provide information that is essential for the safe and effective use of the corresponding drug. Specifically, these assays are Ventana SP142 for atezolizumab (anti-PD-L1) in patients with urothelial carcinoma, triple-negative breast cancer or NSCLC; Dako 288 for nivolumab (anti-PD1) in combination with ipilimumab (anti-CTLA-4) in patients with NSCLC and Dako 22C3 for pembrolizumab (anti-PD1) in different solid tumors [56]. The FDA has indicated Ventana SP263 and Dako 28-8 as complementary diagnostics for nivolumab in advanced NSCLC and durvalumab (anti-PD-L1) for advanced urothelial carcinoma $[57,58]$. This means that such tests identify subsets of patients that might respond well to the therapy, but are not prerequisites for receiving the drug.

Different commercially available assays may thus be used to make important clinical decisions; however, in clinical practice, it is challenging to make all such testing available to patients. In this regard, harmonization studies to analyze results obtained with different antibodies have been conducted [59-61]. Taken together, these studies suggest that three PD-L1 assays protocols (SP263, 22C3 and 28-8) have similar analytical performance and can be used interchangeably. However, our group has demonstrated that although assays 22C3 and SP263 appear to be comparable in terms of overall agreement, they show important discrepancies in identifying positive cases at clinically relevant cutoffs [62] (Figure 1). Another key issue is that each validated assay must be performed onto a dedicated autostainer (e.g., 22C3 on AutostainerLink48). However, it is not possible for all laboratories to have all platforms; therefore, in many cases, the PD-L1 IHC tests are performed on different staining platforms as laboratory developed tests (LDT). In this regard, a meta-analysis on the performance of different PD-L1 assays concluded that properly validated LDTs used for the same purpose of a validated PD-L1 assay can perform better than another approved assay that was developed for a different purpose [63]. On this point, we could demonstrate that with an optimized protocol, the non-validated PD-L1 clone E1L3N shows high levels of overall agreement with the SP263 assay in NSCLC [64].

In addition to the complexity related to the different staining performances of the immunohistochemical assays, another issue is represented by the fact that different scoring methods evaluating various cellular compartments within the tumors have been developed. In fact, in clinical trials on pembrolizumab and nivolumab, the predictive potential of PD-L1 expression has been based on its evaluation on tumor cells only using the tumor proportion score (TPS)/tumor cells (TCs), which is defined as the percentage of PD-L1-positive tumor cells (partial or complete) relative to the total number of viable tumor cells $[65,66]$. On the other hand, in trials assessing atezolizumab, PD-L1 expression has been evaluated on immune cells (ICs) using SP142 as the percentage of tumor area infiltrated by PDL1-positive immune cells relative to the total tumor area $[67,68]$. TPS/TC scoring has shown good interobserver agreement, while the IC algorithm is characterized by poor reproducibility among pathologists $[69,70]$. In other trials evaluating pembrolizumab in a variety of solid tumors, a combined score has been developed, called combined 
positive score (CPS) and is defined as the percentage of immune cells (lymphocytes and macrophages) and tumor cells relative to the total number of viable tumor cells. For CPS, only a few trials have evaluated the reproducibility of the algorithm, with contrasting results $[71,72]$. Therefore, further studies assessing the reproducibility of CPS are needed.

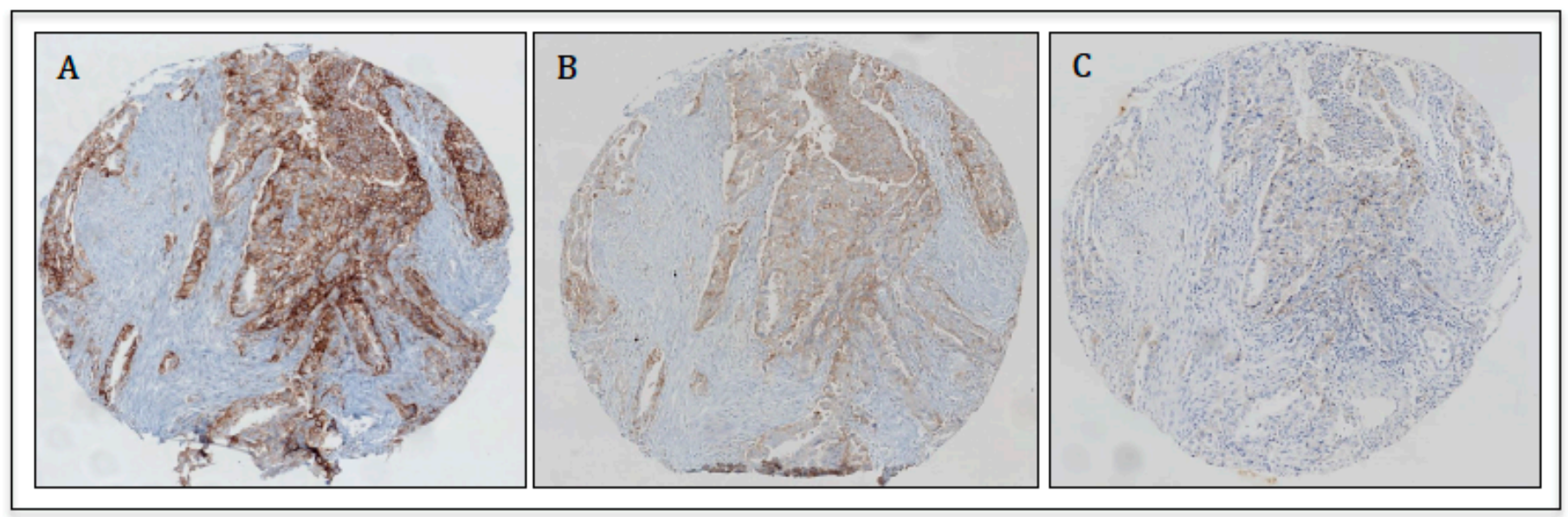

Figure 1. Representative image of PD-L1 expression on the same core with different assays (10× magnification): (A) SP263 on Ventana platform; (B) 22C3 on Ventana platform; (C) 22C3 on Dako platform.

Intratumor heterogeneity is another known challenge that can hamper PD-L1 determination and its predictive value. In clinical practice, tumor tissue can be obtained from surgical specimens, core needle biopsies and fine needle aspiration. Moreover, for most patients, only one lesion is sampled, even in the presence of multiple metastases. In this regard, correlative biomarker studies related to immune checkpoint inhibitor trials contain a heterogeneous mix of sample types and sites; therefore, the question on the most appropriate sample for PD-L1 testing remains unanswered. We and others have demonstrated striking topographical PD-L1 expression differences in NSCLC, especially in adenocarcinomas, which is not attributable to morphology alone but likely underpins subclonal evolution $[73,74]$. In this setting, we found that the best concordance between tissue microarrays cores (used as surrogate of biopsies) and whole sections (used as the reference) varies according to the PD-L1 expression cutoff used and found that three biopsies showed high sensitivity and specificity [75].

Cytology samples often represent the only available diagnostic material for a considerable proportion of metastatic patients but are generally not used in clinical trials for PD-L1 determination. Cell blocks are accepted for PD-L1 TPS scoring since they present a good correlation with histology [74]; on the other hand, in clinical practice, the possibility of having cytologic smears as the only available diagnostic material on which to perform predictive tests occurs in up to $16 \%$ of cases. In an exploratory analysis, we compared PD-L1 staining between cytological smears and whole sections from NSCLC cases and found an overall agreement of $90 \%$. Specifically, we found absolute concordance between smears with PD-L1 expressed in $<10 \%$ and $\geq 50 \%$ of cells and whole sections with PD-L1 expressed in $<50 \%$ and $\geq 50 \%$ of cells, respectively. Therefore, immunocytochemistry on cytological smears can be considered a reliable method for the evaluation of PD-L1 expression at the $50 \%$ cutoff when positive cells are $<10 \%$ or $\geq 50 \%$. However, for cytological smears showing PD-L1 expression in $10-49 \%$ of cells, additional tissue sampling may be necessary [76].

Despite the standardization of technical procedures, a number of studies have demonstrated substantial variations between pathologists in the interpretation of PD-L1 staining, with disagreement in up to $25 \%$ of cases at a TPS cutoff of $1 \%$ [70,77]. Although the clinical impact of such interobserver variations is unclear, they represent an intrinsic limit of human visual interpretation in providing a quantitative assessment of a biomarker located 
in a heterogeneous context [78]. To this end, more precise approaches to PD-L1 scoring, irrespective of the cell compartment, might benefit from digital pathology and artificial intelligence. Such approach could also allow a more comprehensive evaluation of the immune contexture with the possibility to quantify tumor-infiltrating lymphocytes in light of their possible inclusion in more powerful predictive models. Clearly, such approach would require important infrastructure updates and validations before implementation in clinical practice.

\section{Additional and Novel Strategies to Improve Patient Selection: Beyond PD-L1}

Although the predictive potential of PD-L1 immunohistochemistry can be significantly ameliorated by reducing confounding variables regarding specimen features (biopsies vs. surgical specimens; primary vs. metastasis), interassay variability, scoring system (TPS vs. CPSvs.IC) and interpathologist reproducibility, a single biomarker is unlikely to predict response to treatment with immune checkpoint inhibitors. Therefore, other variables are being evaluated to improve the efficacy of the PD-1/PD-L1 axis blockade and to identify predictive markers for immune checkpoint inhibitors.

\subsection{Tumor Mutational Burden}

Tumor mutational burden (TMB) is defined as the number of somatic mutations $/ \mathrm{Mb}$ of tumor genome. Tumors with a large number of somatic gene mutations develop a higher neoantigen-specific $\mathrm{T}$ cell response, which results in an increased susceptibility to immunotherapy. Consistent with this concept, a high TMB has been shown to predict response to immune checkpoint inhibitors across a diverse range of cancer types, including NSCLC, melanoma, and bladder cancers [79]. The TMB is a very promising biomarker, but it is limited by cost and technological requirements correlated with the whole-exome sequencing (WES) assay, not routinely available in most pathology laboratories. A large panel of targeted next generation sequencing (NGS) has been implemented in clinical practice, and TMB estimations derived from the two methods are highly correlated supporting the use of NGS as a surrogate for WES [80]. On June 2020, the FDA approved the use of pembrolizumab for the treatment of adult and pediatric patients with unresectable or metastatic tumors with a high $\mathrm{TMB}$, defined as $\geq 10$ mutations $/ \mathrm{Mb}$, that have progressed following prior treatment [81]. However, many challenges remain before the implementation of NGS-based TMB as a predictive biomarker in clinical practice: since there are numerous NGS platforms, this poses a major problem in terms of reproducibility and globally accepted predictive TMB (cut-offs have not been determined). Moreover, TMB may be heterogeneous within the tumor, and high TMB alone does not guarantee response to immune checkpoint inhibitors. To this end, there are several examples of patients with low TMB who responded to immune checkpoint inhibitors, as well as cases of patients with high TMB who failed to respond [82].

\subsection{Mismatch Repair Deficiency (dMMR)/Microsatellite Instability (MSI)}

It has been demonstrated that tumors with mismatch repair (MMR) deficiency respond better to PD-1/PD-L1 inhibitors, since they are more prone to express neoantigens [83]. The DNA MMR system recognizes and corrects insertion, deletion and base pair mismatches that occur during DNA replication. dMMR is primarily caused by the inactivation of one or more of the 4 main proteins: MLH1, MSH2, PMS2 and MSH6. dMMR was first detected in colorectal cancer but can occur in many other tumor types [84]. There are 2 main methods of screening for dMMR: IHC for the 4 MMR proteins MLH1, MSH2, PMS2 and MSH6, and molecular testing to detect MSI.

In May 2017, the FDA granted accelerated approval to pembrolizumab for the treatment of unresectable or metastatic dMMR or MSI-high solid tumors that have progressed following prior treatment, the first cancer site-agnostic approval granted from the FDA [85]. 


\subsection{Tumor-Infiltrating Lymphocytes (TILs)}

TILs are lymphocytes migrated within tumor stroma or the tumor itself. TIL presence reflects the dynamic phase of the immune system attempt to contrast tumor growth. Clinically, higher TIL numbers have been associated with improved survival in multiple solid tumor types [86-88]. Within TILs, cytotoxic CD8 ${ }^{+} \mathrm{T}$ lymphocytes are the effector cells, and their presence within the tumor may suggest checkpoint inhibitor efficacy. Several studies have evaluated intratumoral $\mathrm{CD}^{+}$lymphocytes alone or in combination with PD-L1 expression as a predictive biomarker of immunotherapy in different tumors [89,90], showing that PD-L1-expressing tumors lacking an appropriate TIL infiltrate may explain the failure of checkpoint inhibition in a subset of patients. Immunoscore (a standardized immune-based assay that measures intra- and peritumoral $\mathrm{T}$ cell infiltration) and multiplex immunohistochemistry, an antibody-protein labeling methodology that allows the simultaneous assessment of multiple proteins of interest on one slide, represent more advanced ways to evaluate TILs [91,92].

\section{Disruption of PD1/PD-L1 Axis in Cancer Therapy}

The first drugs disrupting the PD1/PD-L1 axis approved by the FDA were nivolumab and pembrolizumab for the treatment of advanced melanoma $[93,94]$. Since then, several trials have been carried out, and several antibodies have been approved in different settings. Indeed, several studies have demonstrated the efficacy of drugs blocking the PD-1/PD-L1 pathway, alone or in combination with other therapies, for the treatment of different adult cancer patients (Table 2). On the contrary, there is a lack of knowledge on the use of antiPD-1/PD-Ls antibodies towards pediatric tumors, and deeper analyses are still required to evaluate their efficacy in childhood cancer patients. We present studies describing PD-1 and PD-Ls expression in neuroblastoma (NB) as well as the ongoing clinical trials aimed to determine the potential role of both anti-PD-1 and anti-PD-L1 mAbs treatments in the context of hematological and solid pediatric cancers.

Table 2. Current indications for anti PD1/PD-L1 therapy in different advanced/metastatic tumor types: NSCLC: non-small cell lung carcinoma; SCLC: small cell lung carcinoma; TNBC: triple negative breast carcinoma; CSCC: cutaneous squamous cell carcinoma; RCC: renal cell carcinoma; UC: urothelial carcinoma; HCC: hepatocellular carcinoma; GEJ: gastro-esophageal junction; MSI: microsatellite instability; dMMR: mismatch repair deficient; HNSCC: head and neck squamous cell carcinoma; HL: Hodgkin lymphoma; PMLBCL: primary mediastinal large B cell lymphoma; wt: wild-type; TPS: tumor proportion score; CPS: combined positive score; IC: tumor-infiltrating immune cell; pembrolizumab, nivolumab, cemiplimab: anti-PD-1; atezolizumab, durvalumab, avelumab: anti-PD-L1.

\begin{tabular}{lll}
\hline Type & Treatment & Indications (Ref) \\
\hline NSCLC & Pembrolizumab & I line (ALK and EGFR wt, TPS $\geq 1 \%$ ) [95] \\
& II line (TPS $\geq$ 1\%) [96]
\end{tabular}


Table 2. Cont.

\begin{tabular}{|c|c|c|}
\hline Type & Treatment & Indications (Ref) \\
\hline Melanoma & Pembrolizumab, Nivolumab & $\begin{array}{l}\text { Adjuvant treatment after radical surgery }[108,109] \\
\text { I line }[110,111] \text {; II line }[93,112]\end{array}$ \\
\hline \multirow[t]{2}{*}{ Merkel cell carcinoma } & Pembrolizumab & I line [113] \\
\hline & Avelumab & II line [114] \\
\hline CSCC & Cemiplimab & I line [115] \\
\hline \multirow[t]{2}{*}{ RCC } & Nivolumab + ipilimumab & I-II line $[116,117]$ \\
\hline & Pembrolizumab/avelumab + axitinib & I line $[118,119]$ \\
\hline \multirow[t]{3}{*}{$\mathrm{UC}$} & Pembrolizumab & $\begin{array}{l}\text { I line in patients ineligible for cisplatin-containing } \\
\text { therapy }(\mathrm{CPS} \geq 10 \%) \text {, or patients unfit for } \\
\text { platinum-containing chemotherapy [120] }\end{array}$ \\
\hline & Atezolizumab & $\begin{array}{l}\text { I line in patients ineligible for cisplatin-containing } \\
\text { therapy (IC } \geq 5 \% \text { ), or patients unfit for } \\
\text { platinum-containing chemotherapy [121] }\end{array}$ \\
\hline & $\begin{array}{l}\text { Atezolizumab, Nivolumab, Durvalumab, } \\
\text { Avelumab, Pembrolizumab }\end{array}$ & $\begin{array}{l}\text { Disease progression during or after platinum-based } \\
\text { chemotherapy or within one year after adjuvant or } \\
\text { neoadjuvant chemotherapy }[120,122-125]\end{array}$ \\
\hline Cervical cancer & Pembrolizumab & II line (CPS $\geq 1 \%$ ) [126] \\
\hline $\mathrm{HCC}$ & Nivolumab/Pembrolizumab & II line $[127,128]$ \\
\hline Esophageal cancer & Pembrolizumab & II line (CPS $\geq 10 \%$ ) [129] \\
\hline Gastric/GEJ adenocarcinoma & Pembrolizumab & II line (CPS $\geq 1 \%$ ) [130] \\
\hline MSI-H dMMR cancers & Pembrolizumab & II line irrespective of primary location [131] \\
\hline \multirow[t]{2}{*}{ HNSCC } & Pembrolizumab & I line (CPS $\geq 1 \%$ ) [132] \\
\hline & Pembrolizumab/Nivolumab & II line $[133,134]$ \\
\hline HL & Pembrolizumab & II line [135] \\
\hline PMLBCL & Pembrolizumab & II line [136] \\
\hline
\end{tabular}

\section{Neuroblastoma and Other Pediatric Tumors}

The development of drugs targeting immune checkpoint inhibitors has mainly focused on adult cancers. However, in recent years, there has been a push to evaluate the application of these immunotherapeutic approaches to pediatric tumors. Indeed, PD-L1 expression has been observed in several pediatric hematological tumors, such as Hodgkin lymphoma, diffuse large B cell lymphoma (DLBCL), acute myeloid leukemia, acute lymphoblastic leukemia and glioma [137-141]. Despite the high PD-L1 abundance in hematological malignancies, its expression in pediatric solid tumors is relatively low and variable in different histotypes. Thus, PD-L1 expression was detected in the $72 \%$ of NB patients where it was found to correlate with a lower survival rate [142]. In addition, Dondero and colleagues demonstrated that lymphocytes derived from bone marrow samples of metastatic NB patients expressed PD-1, and produced IFN- $\gamma$ that could in turn induce PD-L1 expression in tumor cells [13]. Considering the potential susceptibility of NB to immunotherapy, different studies have been developed to evaluate the efficacy of PD-1/PD-L1 axis disruption-based therapies. Thus, there are several ongoing clinical trials aimed to determine the potential role of both anti-PD-1 and anti-PD-L1 mAbs treatments. A phase I trial is also analyzing a combination therapy with anti-GD2, 131-1 Metaiodobenzylguanidine (mlBG) and Nivolumab in treating patients with relapsed and refractory NB (NCT02914405) [143]. In addition, a recent multicentric, phase 1-2 trial was performed using Nivolumab, with or without ipilimumab combination (NCT02304458) in pediatric patients with different tumors, including rhabdomyosarcoma, Ewing sarcoma, osteosarcoma, neuroblastoma, Hodgkin lymphoma, non-Hodgkin lymphoma and melanoma 
diseases. The results indicated that Nivolumab was safe and well tolerated in children and young adults and showed clinical benefits in lymphoma, while no significant single-agent activity was observed in the other pediatric solid tumors. Importantly, however, this study defines the recommended phase 2 dose and establishes a Nivolumab safety profile for children, which can serve as the basis for its potential study in combination regimens for childhood cancers [144,145]. In this context, an actively recruiting Phase II clinical trial is evaluating the efficacy of Nivolumab in combination with ipilimumab in children with high-grade primary central nervous system (CNS) malignancies (NCT03130959) [141]. The efficacy of Nivolumab in combination with lirilumab, a human monoclonal antibody that binds the KIR2DL1/2L3 receptor, is under investigation in refractory and recurrent malignancies (NCT02813135) [143]. Moreover, a trial that began in 2018 is evaluating the role of Nivolumab in combination with chemotherapy for the treatment of solid tumors and lymphoma (NCT03585465).

Pembrolizumab was approved by the FDA in 2017 for the treatment of children with refractory Hodgkin lymphoma or patients with relapsed tumors [145]. An ongoing clinical trial is investigating the use of Pembrolizumab in children with PD-L1-positive advanced, relapsed or refractory solid tumors or lymphoma or with advanced melanoma (NCT02332668).

\section{Concluding Remarks}

In recent years, immunotherapy with antibodies disrupting the PD-1/PD-L1 axis revealed an unprecedented breakthrough in the treatment of different tumors. This resulted in a true revolution in the cure of highly aggressive cancers. However, despite this progress, a large fraction of patients do not benefit from the use of ICIs. As discussed in this contribution, further improvements may be reached by a more accurate patient selection. This may be based not only on the standardization of available reagents and methods, such as PD-L1 expression and frequency of TILs, but also on the evaluation of other inhibitory checkpoints which may impair antitumor immune responses, independent of PD-1/PD-L1 interactions. Along this line, other major mechanisms play an important role in dampening immune responses. Thus, different cell types, present in the tumor microenvironment, exploit an array of immunosuppressive mechanisms, which "freeze" effector cells, thus hampering their antitumor activity. For example, myeloid-derived suppressor cells (MDSCs), a heterogeneous immature myeloid population, are able to interact with immune cells, compromising their effector function. Of note, the PD1/PD-L1 axis is among the know mechanisms adopted by MDSCs to suppress the immune effector function of T and NK cells. In particular, the surface expression of PD-L1 correlates with the impairment of tumor-infiltrating lymphocytes (TILs) and with tumor progression/prognosis. In TME, tumor cells and their soluble mediators can induce PD-L1 expression on tumor-infiltrating MDSCs [146,147]. Thus, PD-L1 expressed by MDSCs can suppress NK and T cell activity. In different tumor types, increased PD-L1 + MDSC has been detected and, in some instances, a correlation between the percentage of PD-L1 + MDSC and disease stages or clinical outcome has been reported [148]. In addition, Nitric Oxide (NO) produced by MDSCs has a potent inhibitory effect on NK cells by impairing the Fc receptor-mediated killing, the secretion of IFN- $\gamma$, TNF- $\alpha$ and Granzyme B, as detected in MDSC-co-cultured NK cells $[149,150]$. Other important cells, which favor tumor growth and inhibit antitumor immune responses, are the polarized M2 macrophages, which act both directly by secreting different inhibitory factors and cytokines, and indirectly by inducing suppressive cells and favoring fibrotic reactions [151]. Recognition of the prevalent mechanism(s) operating in given tumors may allow the selective removal of the inhibitory effect, either by specifically targeting suppressive cells (e.g., MDSCs or M2 macrophages) or their soluble products. Thus, the use of combination therapies suitable for given tumors appear to be particularly promising. Of note, novel cell-based adoptive therapies (e.g., CAR-T or CAR-NK cells), although very promising, may encounter similar hurdles, including the PD-1 (or other checkpoint) expression on the engineered cells themselves and the suppressive TME which would render their 
antitumor activity inefficient. Thus, improvement/standardization of available and new diagnostic approaches allowing the identification of the major suppressive mechanisms in a given tumor may lead to more effective, patient-tailored, tumor therapies.

Author Contributions: Writing and original draft preparation, E.M., F.R.M. and L.M.; Writing and editing, E.M., F.R.M., L.Q., P.B., N.T., P.V., A.E., F.C., M.B., G.M., G.B. and L.M. All authors have read and agreed to the published version of the manuscript.

Funding: This work was supported by grants awarded by Associazione Italiana per la Ricerca sul Cancro (AIRC) - Special Program on Metastatic disease: the key unmet need in oncology 5X1000 2018 Id. 21147 (L.M.), AIRC IG 2017 Id. 19920 (L.M.) and RC-2020 OPBG (L.M. and P.V.); F.R.M. is a recipient of the Fondazione Umberto Veronesi fellowship. L.Q. received funding from AIRC and from the European Union's Horizon 2020 research and innovation program under the Marie Skłodowska-Curie grant agreement no. 800924.

Conflicts of Interest: The authors declare no conflict of interest. The funders had no role in the design of the study; in the collection, analyses, or interpretation of data; in the writing of the manuscript, or in the decision to publish the results.

\section{References}

1. Ishida, Y.; Agata, Y.; Shibahara, K.; Honjo, T. Induced expression of PD-1, a novel member of the immunoglobulin gene superfamily, upon programmed cell death. EMBO J. 1992, 11, 3887-3895. [CrossRef] [PubMed]

2. Nishimura, H.; Minato, N.; Nakano, T.; Honjo, T. Immunological studies on PD-1-deficient mice: Implication of PD-1 as a negative regulator for B cell responses. Int. Immunol. 1998, 10, 1563-1572. [CrossRef]

3. Nishimura, H.; Nose, M.; Hiai, H.; Minato, N.; Honjo, T. Development of lupus-like autoimmune diseases by disruption of the PD-1 gene encoding an ITIM motif-carrying immunoreceptor. Immunity 1999, 11, 141-151. [CrossRef]

4. Boussiotis, V.A.; Chatterjee, P.; Li, L. Biochemical signaling of PD-1 on T cells and its functional implications. Cancer J. USA 2014, 20, 265-271. [CrossRef] [PubMed]

5. Chamoto, K.; Al-Habsi, M.; Honjo, T. Role of PD-1 in immunity and diseases. In Current Topics in Microbiology and Immunology; Springer: Berlin/Heidelberg, Germany, 2017; Volume 410, pp. 75-97.

6. Huang, A.C.; Postow, M.A.; Orlowski, R.J.; Mick, R.; Bengsch, B.; Manne, S.; Xu, W.; Harmon, S.; Giles, J.R.; Wenz, B.; et al. T-cell invigoration to tumour burden ratio associated with anti-PD-1 response. Nature 2017, 545, 60-65. [CrossRef]

7. Pesce, S.; Greppi, M.; Tabellini, G.; Rampinelli, F.; Parolini, S.; Olive, D.; Moretta, L.; Moretta, A.; Marcenaro, E. Identification of a subset of human natural killer cells expressing high levels of programmed death 1: A phenotypic and functional characterization. J. Allergy Clin. Immunol. 2017, 139, 335-346. [CrossRef] [PubMed]

8. Keir, M.E.; Liang, S.C.; Guleria, I.; Latchman, Y.E.; Qipo, A.; Albacker, L.A.; Koulmanda, M.; Freeman, G.J.; Sayegh, M.H.; Sharpe, A.H. Tissue expression of PD-L1 mediates peripheral T cell tolerance. J. Exp. Med. 2006, 203, 883-895. [CrossRef]

9. Latchman, Y.; Wood, C.R.; Chernova, T.; Chaudhary, D.; Borde, M.; Chernova, I.; Iwai, Y.; Long, A.J.; Brown, J.A.; Nunes, R.; et al. PD-L2 is a second ligand for PD-1 and inhibits T cell activation. Nat. Immunol. 2001, 2, 261-268. [CrossRef]

10. Keir, M.E.; Butte, M.J.; Freeman, G.J.; Sharpe, A.H. PD-1 and its ligands in tolerance and immunity. Annu. Rev. Immunol. 2008, 26, 677-704. [CrossRef]

11. Simon, S.; Labarriere, N. PD-1 expression on tumor-specific T cells: Friend or foe for immunotherapy? Oncoimmunology 2018, 7, e1364828. [CrossRef]

12. Ahmadzadeh, M.; Johnson, L.A.; Heemskerk, B.; Wunderlich, J.R.; Dudley, M.E.; White, D.E.; Rosenberg, S.A. Tumor antigenspecific CD8 T cells infiltrating the tumor express high levels of PD-1 and are functionally impaired. Blood 2009, 114, 1537-1544. [CrossRef]

13. Dondero, A.; Pastorino, F.; Della Chiesa, M.; Corrias, M.V.; Morandi, F.; Pistoia, V.; Olive, D.; Bellora, F.; Locatelli, F.; Castellano, A.; et al. PD-L1 expression in metastatic neuroblastoma as an additional mechanism for limiting immune surveillance. Oncoimmunology 2016, 5. [CrossRef] [PubMed]

14. Brody, R.; Zhang, Y.; Ballas, M.; Siddiqui, M.K.; Gupta, P.; Barker, C.; Midha, A.; Walker, J. PD-L1 expression in advanced NSCLC: Insights into risk stratification and treatment selection from a systematic literature review. Lung Cancer 2017, 112, $200-215$. [CrossRef] [PubMed]

15. Cha, J.H.; Chan, L.C.; Li, C.W.; Hsu, J.L.; Hung, M.C. Mechanisms controlling PD-L1 expression in cancer. Mol. Cell 2019, 76, 359-370. [CrossRef]

16. Chiossone, L.; Vivier, E. Immune checkpoints on innate lymphoid cells. J. Exp. Med. 2017, 214, 1561-1563. [CrossRef]

17. Davis, A.A.; Patel, V.G. The role of PD-L1 expression as a predictive biomarker: An analysis of all US food and drug administration (FDA) approvals of immune checkpoint inhibitors. J. Immunother. Cancer 2019, 7. [CrossRef]

18. Mahoney, K.M.; Freeman, G.J.; McDermott, D.F. The next immune-checkpoint inhibitors: Pd-1/pd-11 blockade in melanoma. Clin. Ther. 2015, 37, 764-782. [CrossRef]

19. Sharma, P.; Allison, J.P. The future of immune checkpoint therapy. Science 2015, 348, 56-61. [CrossRef] [PubMed] 
20. Wherry, E.J. T cell exhaustion. Nat. Immunol. 2011, 12, 492-499. [CrossRef] [PubMed]

21. Thommen, D.S.; Schreiner, J.; Müller, P.; Herzig, P.; Roller, A.; Belousov, A.; Umana, P.; Pisa, P.; Klein, C.; Bacac, M.; et al. Progression of lung cancer is associated with increased dysfunction of T cells defined by coexpression of multiple inhibitory receptors. Cancer Immunol. Res. 2015, 3, 1344-1354. [CrossRef]

22. Chapon, M.; Randriamampita, C.; Maubec, E.; Badoual, C.; Fouquet, S.; Wang, S.-F.; Marinho, E.; Farhi, D.; Garcette, M.; Jacobelli, S.; et al. Progressive upregulation of PD-1 in primary and metastatic melanomas associated with blunted TCR signaling in infiltrating T lymphocytes. J. Investig. Derm. 2011, 131, 1300-1307. [CrossRef]

23. Gros, A.; Robbins, P.F.; Yao, X.; Li, Y.F.; Turcotte, S.; Tran, E.; Wunderlich, J.R.; Mixon, A.; Farid, S.; Dudley, M.E.; et al. PD-1 identifies the patient-specific CD8+ tumor-reactive repertoire infiltrating human tumors. J. Clin. Investig. 2014, 124, $2246-2259$. [CrossRef]

24. Montler, R.; Bell, R.B.; Thalhofer, C.; Leidner, R.; Feng, Z.; Fox, B.A.; Cheng, A.C.; Bui, T.G.; Tucker, C.; Hoen, H.; et al. OX40, PD-1 and CTLA-4 are selectively expressed on tumor-infiltrating T cells in head and neck cancer. Clin. Transl. Immunol. 2016, 5, e70. [CrossRef] [PubMed]

25. Kim, H.D.; Song, G.W.; Park, S.; Jung, M.K.; Kim, M.H.; Kang, H.J.; Yoo, C.; Yi, K.; Kim, K.H.; Eo, S.; et al. Association between expression level of PD1 by tumor-infiltrating CD8+ T cells and features of hepatocellular carcinoma. Gastroenterology 2018, 155, 1936-1950. [CrossRef]

26. Zhao, Y.J.; Zhang, J.; Shi, F.; Hu, Z.P.; Wu, J.P.; Wu, G.J.; Wang, R.B.; Zhou, Q.; Chang, H.; Li, Y.N.; et al. Expression of PD-1 on $\mathrm{CD} 4+$ tumor-infiltrating lymphocytes in tumor microenvironment associated with pathological characteristics of breast cancer. J. Immunol. Res. 2018, 2018, 5690258. [CrossRef]

27. Kumagai, S.; Togashi, Y.; Kamada, T.; Sugiyama, E.; Nishinakamura, H.; Takeuchi, Y.; Vitaly, K.; Itahashi, K.; Maeda, Y.; Matsui, S.; et al. The PD-1 expression balance between effector and regulatory T cells predicts the clinical efficacy of PD-1 blockade therapies. Nat. Immunol. 2020, 21, 1346-1358. [CrossRef]

28. Mazzaschi, G.; Madeddu, D.; Falco, A.; Bocchialini, G.; Goldoni, M.; Sogni, F.; Armani, G.; Lagrasta, C.A.; Lorusso, B.; Mangiaracina, C.; et al. Low PD-1 expression in cytotoxic CD8 + tumor-infiltrating lymphocytes confers an immune-privileged tissue microenvironment in NSCLC with a prognostic and predictive value. Clin. Cancer Res. 2018, 24, 407-419. [CrossRef]

29. Cader, F.Z.; Schackmann, R.C.J.; Hu, X.; Wienand, K.; Redd, R.; Chapuy, B.; Ouyang, J.; Paul, N.; Gjini, E.; Lipschitz, M.; et al. Mass cytometry of Hodgkin lymphoma reveals a CD41 regulatory T-cell-rich and exhausted T-effector microenvironment. Blood 2018, 132, 825-836. [CrossRef] [PubMed]

30. Myklebust, J.H.; Irish, J.M.; Brody, J.; Czerwinski, D.K.; Houot, R.; Kohrt, H.E.; Timmerman, J.; Said, J.; Green, M.R.; Delabie, J.; et al. High PD-1 expression and suppressed cytokine signaling distinguish T cells infiltrating follicular lymphoma tumors from peripheral T cells. Blood 2013, 121, 1367-1376. [CrossRef] [PubMed]

31. Li, X.; Wang, R.; Fan, P.; Yao, X.; Qin, L.; Peng, Y.; Ma, M.; Asley, N.; Chang, X.; Feng, Y.; et al. A comprehensive analysis of key immune checkpoint receptors on tumor-infiltrating t cells from multiple types of cancer. Front. Oncol. 2019, 9. [CrossRef]

32. Tassi, E.; Grazia, G.; Vegetti, C.; Bersani, I.; Bertolini, G.; Molla, A.; Baldassari, P.; Andriani, F.; Roz, L.; Sozzi, G.; et al. Early effector T lymphocytes coexpress multiple inhibitory receptors in primary non-small cell lung cancer. Cancer Res. 2017, 77, 851-861. [CrossRef] [PubMed]

33. Zhou, G.; Sprengers, D.; Boor, P.P.C.; Doukas, M.; Schutz, H.; Mancham, S.; Pedroza-Gonzalez, A.; Polak, W.G.; de Jonge, J.; Gaspersz, M.; et al. Antibodies against immune checkpoint molecules restore functions of tumor-infiltrating $t$ cells in hepatocellular carcinomas. Gastroenterology 2017, 153, 1107-1119. [CrossRef] [PubMed]

34. Jinhua, X.; Ji, W.; Shouliang, C.; Liangfeng, Z.; Feiyue, J.; Lin, Y.; Yan, Z.; Haoming, J. Expression of immune checkpoints in T cells of esophageal cancer patients. Oncotarget 2016, 7, 63669-63678. [CrossRef]

35. Egelston, C.A.; Avalos, C.; Tu, T.Y.; Simons, D.L.; Jimenez, G.; Jung, J.Y.; Melstrom, L.; Margolin, K.; Yim, J.H.; Kruper, L.; et al. Human breast tumor-infiltrating CD8+ T cells retain polyfunctionality despite PD-1 expression. Nat. Commun. 2018, 9. [CrossRef]

36. Benson, D.M.; Bakan, C.E.; Mishra, A.; Hofmeister, C.C.; Efebera, Y.; Becknell, B.; Baiocchi, R.A.; Zhang, J.; Yu, J.; Smith, M.K.; et al. The PD-1/PD-L1 axis modulates the natural killer cell versus multiple myeloma effect: A therapeutic target for CT-011, a novel monoclonal anti-PD-1 antibody. Blood 2010, 116, 2286-2294. [CrossRef]

37. Liu, Y.; Cheng, Y.; Xu, Y.; Wang, Z.; Du, X.; Li, C.; Peng, J.; Gao, L.; Liang, X.; Ma, C. Increased expression of programmed cell death protein 1 on NK cells inhibits NK-cell-mediated anti-tumor function and indicates poor prognosis in digestive cancers. Oncogene 2017, 36, 6143-6153. [CrossRef]

38. Beldi-Ferchiou, A.; Lambert, M.; Dogniaux, S.; Vély, F.; Vivier, E.; Olive, D.; Dupuy, S.; Levasseur, F.; Zucman, D.; Lebbé, C.; et al. PD-1 mediates functional exhaustion of activated NK cells in patients with Kaposi sarcoma. Oncotarget 2016, 7, 72961-72977. [CrossRef]

39. Vari, F.; Arpon, D.; Keane, C.; Hertzberg, M.S.; Talaulikar, D.; Jain, S.; Cui, Q.; Han, E.; Tobin, J.; Bird, R.; et al. Immune evasion via PD-1/PD-L1 on NK cells and monocyte/macrophages is more prominent in Hodgkin lymphoma than DLBCL. Blood 2018, 131, 1809-1819. [CrossRef]

40. MacFarlane, A.W.; Jillab, M.; Plimack, E.R.; Hudes, G.R.; Uzzo, R.G.; Litwin, S.; Dulaimi, E.; Al-Saleem, T.; Campbell, K.S. PD-1 expression on peripheral blood cells increases with stage in renal cell carcinoma patients and is rapidly reduced after surgical tumor resection. Cancer Immunol. Res. 2014, 2, 320-331. [CrossRef] 
41. Hsu, J.; Hodgins, J.J.; Marathe, M.; Nicolai, C.J.; Bourgeois-Daigneault, M.C.; Trevino, T.N.; Azimi, C.S.; Scheer, A.K.; Randolph, H.E.; Thompson, T.W.; et al. Contribution of NK cells to immunotherapy mediated by PD-1/PD-L1 blockade. J. Clin. Investig. 2018, 128, 4654-4668. [CrossRef]

42. Niu, C.; Li, M.; Zhu, S.; Chen, Y.; Zhou, L.; Xu, D.; Xu, J.; Li, Z.; Li, W.; Cui, J. Pd-1-positive natural killer cells have a weaker antitumor function than that of pd-1-negative natural killer cells in lung cancer. Int. J. Med. Sci. 2020, 17, 1964-1973. [CrossRef] [PubMed]

43. Trefny, M.P.; Kaiser, M.; Stanczak, M.A.; Herzig, P.; Savic, S.; Wiese, M.; Lardinois, D.; Läubli, H.; Uhlenbrock, F.; Zippelius, A. PD-1+ natural killer cells in human non-small cell lung cancer can be activated by PD-1/PD-L1 blockade. Cancer Immunol. Immunother. 2020, 69, 1505-1517. [CrossRef]

44. Tumino, N.; Martini, S.; Munari, E.; Scordamaglia, F.; Besi, F.; Mariotti, F.R.; Bogina, G.; Mingari, M.C.; Vacca, P.; Moretta, L. Presence of innate lymphoid cells in pleural effusions of primary and metastatic tumors: Functional analysis and expression of PD-1 receptor. Int. J. Cancer 2019, 145, 1660-1668. [CrossRef] [PubMed]

45. Salimi, M.; Wang, R.; Yao, X.; Li, X.; Wang, X.; Hu, Y.; Chang, X.; Fan, P.; Dong, T.; Ogg, G. Activated innate lymphoid cell populations accumulate in human tumour tissues. BMC Cancer 2018, 18. [CrossRef]

46. Mallett, G.; Laurence, A.; Amarnath, S. Programmed cell death-1 receptor (Pd-1)-mediated regulation of innate lymphoid cells. Int. J. Mol. Sci. 2019, 20, 2836. [CrossRef]

47. Quatrini, L.; Vacca, P.; Tumino, N.; Besi, F.; Di Pace, A.L.; Scordamaglia, F.; Martini, S.; Munari, E.; Mingari, M.C.; Ugolini, S.; et al. Glucocorticoids and the cytokines IL-12, IL-15, and IL-18 present in the tumor microenvironment induce PD-1 expression on human natural killer cells. J. Allergy Clin. Immunol. 2021, 147, 349-360. [CrossRef] [PubMed]

48. Quatrini, L.; Wieduwild, E.; Escaliere, B.; Filtjens, J.; Chasson, L.; Laprie, C.; Vivier, E.; Ugolini, S. Endogenous glucocorticoids control host resistance to viral infection through the tissue-specific regulation of PD-1 expression on NK cells. Nat. Immunol. 2018, 19, 954-962. [CrossRef]

49. Xing, K.; Gu, B.; Zhang, P.; Wu, X. Dexamethasone enhances programmed cell death 1 (PD-1) expression during T cell activation: An insight into the optimum application of glucocorticoids in anti-cancer therapy. BMC Immunol. 2015, 16. [CrossRef]

50. Maeda, N.; Maruhashi, T.; Sugiura, D.; Shimizu, K.; Okazaki, I.M.; Okazaki, T. Glucocorticoids potentiate the inhibitory capacity of programmed cell death 1 by up-regulating its expression on T cells. J. Biol. Chem. 2019, 294, 19896-19906. [CrossRef]

51. Acharya, N.; Madi, A.; Zhang, H.; Klapholz, M.; Escobar, G.; Dulberg, S.; Christian, E.; Ferreira, M.; Dixon, K.O.; Fell, G.; et al. Endogenous glucocorticoid signaling regulates CD8+ T cell differentiation and development of dysfunction in the tumor microenvironment. Immunity 2020, 53, 658-671. [CrossRef]

52. Gaucher, L.; Adda, L.; Séjourné, A.; Joachim, C.; Chaby, G.; Poulet, C.; Liabeuf, S.; Gras-Champel, V.; Masmoudi, K.; Moreira, A.; et al. Impact of the corticosteroid indication and administration route on overall survival and the tumor response after immune checkpoint inhibitor initiation. Ther. Adv. Med. Oncol. 2021, 13. [CrossRef]

53. Garon, E.B.; Hellmann, M.D.; Rizvi, N.A.; Carcereny, E.; Leighl, N.B.; Ahn, M.-J.; Eder, J.P.; Balmanoukian, A.S.; Aggarwal, C.; Horn, L.; et al. Five-year overall survival for patients with advanced non-small-cell lung cancer treated with pembrolizumab: Results from the phase I KEYNOTE-001 study. J. Clin. Oncol. 2019, 37, 2518-2527. [CrossRef] [PubMed]

54. Brahmer, J.R.; Govindan, R.; Anders, R.A.; Antonia, S.J.; Sagorsky, S.; Davies, M.J.; Dubinett, S.M.; Ferris, A.; Gandhi, L.; Garon, E.B.; et al. The society for immunotherapy of cancer consensus statement on immunotherapy for the treatment of non-small cell lung cancer (NSCLC). J. Immunother. Cancer 2018, 6, 75. [CrossRef] [PubMed]

55. Hamid, O.; Robert, C.; Daud, A.; Hodi, F.S.; Hwu, W.J.; Kefford, R.; Wolchok, J.D.; Hersey, P.; Joseph, R.; Weber, J.S.; et al. Five-year survival outcomes for patients with advanced melanoma treated with pembrolizumab in KEYNOTE-001. Ann. Oncol. 2019, 30, 582-588. [CrossRef]

56. US Food and Drug Administration. List of Cleared or Approved Companion Diagnostic Devices (In Vitro and Imaging Tools); US Food and Drug Administration: Silver Spring, MD, USA, 2021.

57. US Food and Drug Administration. Durvalumab (Imfinzi); US Food and Drug Administration: Silver Spring, MD, USA, 2017.

58. Doroshow, D.B.; Bhalla, S.; Beasley, M.B.; Sholl, L.M.; Kerr, K.M.; Gnjatic, S.; Wistuba, I.I.; Rimm, D.L.; Tsao, M.S.; Hirsch, F.R. PD-L1 as a biomarker of response to immune-checkpoint inhibitors. Nat. Rev. Clin. Oncol. 2021. [CrossRef]

59. Hirsch, F.R.; McElhinny, A.; Stanforth, D.; Ranger-Moore, J.; Jansson, M.; Kulangara, K.; Richardson, W.; Towne, P.; Hanks, D.; Vennapusa, B.; et al. PD-L1 Immunohistochemistry assays for lung cancer: Results from Phase 1 of the blueprint PD-L1 IHC assay comparison project. J. Thorac. Oncol. 2017, 12, 208-222. [CrossRef]

60. Rimm, D.L.; Han, G.; Taube, J.M.; Yi, E.S.; Bridge, J.A.; Flieder, D.B.; Homer, R.; West, W.W.; Wu, H.; Roden, A.C.; et al. A prospective, multi-institutional, pathologist-based assessment of 4 immunohistochemistry assays for PD-L1 expression in non-small cell lung cancer. JAMA Oncol. 2017, 3, 1051-1058. [CrossRef]

61. Grote, H.J.; Feng, Z.; Schlichting, M.; Helwig, C.; Ruisi, M.; Jin, H.; Scheuenpflug, J.; Gann, C.-N.; Su, Z.; Reck, M.; et al. Programmed death-ligand 1 immunohistochemistry assay comparison studies in NSCLC: Characterization of the 73-10 assay. J. Thorac. Oncol. 2020, 15, 1306-1316. [CrossRef]

62. Munari, E.; Rossi, G.; Zamboni, G.; Lunardi, G.; Marconi, M.; Sommaggio, M.; Netto, G.J.; Hoque, M.O.; Brunelli, M.; Martignoni, G.; et al. PD-L1 assays 22C3 and SP263 are not interchangeable in non-small cell lung cancer when considering clinically relevant cutoffs. Am. J. Surg. Pathol. 2018, 42, 1384-1389. [CrossRef] 
63. Torlakovic, E.; Lim, H.J.; Adam, J.; Barnes, P.; Bigras, G.; Chan, A.W.H.; Cheung, C.C.; Chung, J.-H.; Couture, C.; Fiset, P.O.; et al. "Interchangeability" of PD-L1 immunohistochemistry assays: A meta-analysis of diagnostic accuracy. Mod. Pathol. 2020, 33, 4-17. [CrossRef]

64. Munari, E.; Zamboni, G.; Lunardi, G.; Marconi, M.; Brunelli, M.; Martignoni, G.; Netto, G.J.; Quatrini, L.; Vacca, P.; Moretta, L.; et al. PD-L1 expression in non-small cell lung cancer: Evaluation of the diagnostic accuracy of a laboratory-developed test using clone E1L3N in comparison with 22C3 and SP263 assays. Hum. Pathol. 2019, 90, 54-59. [CrossRef] [PubMed]

65. Kerr, K.M.; Tsao, M.-S.; Nicholson, A.G.; Yatabe, Y.; Wistuba, I.I.; Hirsch, F.R. Programmed death-ligand 1 immunohistochemistry in lung cancer: In what state is this art? J. Thorac. Oncol. 2015, 10, 985-989. [CrossRef] [PubMed]

66. Kerr, K.M.; Hirsch, F.R. Programmed death ligand-1 immunohistochemistry: Friend or foe? Arch. Pathol. Lab. Med. 2016, 140, 326-331. [CrossRef] [PubMed]

67. Fehrenbacher, L.; Spira, A.; Ballinger, M.; Kowanetz, M.; Vansteenkiste, J.; Mazieres, J.; Park, K.; Smith, D.; Artal-Cortes, A.; Lewanski, C.; et al. Atezolizumab versus docetaxel for patients with previously treated non-small-cell lung cancer (POPLAR): A multicentre, open-label, phase 2 randomised controlled trial. Lancet 2016, 387, 1837-1846. [CrossRef]

68. Vennapusa, B.; Baker, B.; Kowanetz, M.; Boone, J.; Menzl, I.; Bruey, J.-M.; Fine, G.; Mariathasan, S.; McCaffery, I.; Mocci, S.; et al. Development of a PD-L1 Complementary Diagnostic Immunohistochemistry Assay (SP142) for Atezolizumab. Appl. Immunohistochem. Mol. Morphol. 2019, 27, 92-100. [CrossRef]

69. Tsao, M.S.; Kerr, K.M.; Kockx, M.; Beasley, M.-B.; Borczuk, A.C.; Botling, J.; Bubendorf, L.; Chirieac, L.; Chen, G.; Chou, T.-Y.; et al. PD-L1 immunohistochemistry comparability study in real-life clinical samples: Results of blueprint phase 2 project. J. Thorac. Oncol. 2018, 13, 1302-1311. [CrossRef] [PubMed]

70. Cooper, W.A.; Russell, P.A.; Cherian, M.; Duhig, E.E.; Godbolt, D.; Jessup, P.J.; Khoo, C.; Leslie, C.; Mahar, A.; Moffat, D.F.; et al. Intra- and interobserver reproducibility assessment of PD-L1 biomarker in non-small cell lung cancer. Clin. Cancer Res. 2017, 23, 4569-4577. [CrossRef]

71. Kulangara, K.; Zhang, N.; Corigliano, E.; Guerrero, L.; Waldroup, S.; Jaiswal, D.; MS, M.J.; Shah, S.; Hanks, D.; Wang, J.; et al. Clinical utility of the combined positive score for programmed death ligand-1 expression and the approval of pembrolizumab for treatment of gastric cancer. Arch. Pathol. Lab. Med. 2019, 143, 330-337. [CrossRef] [PubMed]

72. Park, Y.; Koh, J.; Na, H.Y.; Kwak, Y.; Lee, K.-W.; Ahn, S.-H.; Park, D.J.; Kim, H.-H.; Lee, H.S. PD-L1 Testing in gastric cancer by the combined positive score of the 22C3 PharmDx and SP263 assay with clinically relevant cut-offs. Cancer Res. Treat. 2020, 52, 661-670. [CrossRef] [PubMed]

73. Munari, E.; Zamboni, G.; Marconi, M.; Sommaggio, M.; Brunelli, M.; Martignoni, G.; Netto, G.J.; Moretta, F.; Mingari, M.C.; Salgarello, M.; et al. PD-L1 expression heterogeneity in non-small cell lung cancer: Evaluation of small biopsies reliability. Oncotarget 2017, 8, 90123-90131. [CrossRef]

74. Noll, B.; Wang, W.-L.; Gong, Y.; Zhao, J.; Kalhor, N.; Prieto, V.; Staerkel, G.; Roy-Chowdhuri, S. Programmed death ligand 1 testing in non-small cell lung carcinoma cytology cell block and aspirate smear preparations. Cancer Cytopathol. 2018, 126, 342-352 [CrossRef]

75. Munari, E.; Zamboni, G.; Lunardi, G.; Marchionni, L.; Marconi, M.; Sommaggio, M.; Brunelli, M.; Martignoni, G.; Netto, G.J.; Hoque, M.O.; et al. PD-L1 expression heterogeneity in non-small cell lung cancer: Defining criteria for harmonization between biopsy specimens and whole sections. J. Thorac. Oncol. 2018, 13, 1113-1120. [CrossRef] [PubMed]

76. Munari, E.; Zamboni, G.; Sighele, G.; Marconi, M.; Sommaggio, M.; Lunardi, G.; Rossi, G.; Cavazza, A.; Moretta, F.; Gilioli, E.; et al. Expression of programmed cell death ligand 1 in non-small cell lung cancer: Comparison between cytologic smears, core biopsies, and whole sections using the SP263 assay. Cancer Cytopathol. 2019, 127, 52-61. [CrossRef] [PubMed]

77. Ratcliffe, M.J.; Sharpe, A.; Midha, A.; Barker, C.; Scott, M.; Scorer, P.; Al-Masri, H.; Rebelatto, M.C.; Walker, J. Agreement between programmed cell death ligand-1 diagnostic assays across multiple protein expression cutoffs in non-small cell lung cancer. Clin. Cancer Res. 2017, 23, 3585-3591. [CrossRef] [PubMed]

78. Aeffner, F.; Adissu, H.A.; Boyle, M.C.; Cardiff, R.D.; Hagendorn, E.; Hoenerhoff, M.J.; Klopfleisch, R.; Newbigging, S.; Schaudien, D.; Turner, O.; et al. Digital microscopy, image analysis, and virtual slide repository. ILAR J. 2018, 59, 66-79. [CrossRef] [PubMed]

79. Samstein, R.M.; Lee, C.-H.; Shoushtari, A.N.; Hellmann, M.D.; Shen, R.; Janjigian, Y.Y.; Barron, D.A.; Zehir, A.; Jordan, E.J.; Omuro, A.; et al. Tumor mutational load predicts survival after immunotherapy across multiple cancer types. Nat. Genet. 2019, 51, 202-206. [CrossRef] [PubMed]

80. Roszik, J.; Haydu, L.E.; Hess, K.R.; Oba, J.; Joon, A.Y.; Siroy, A.E.; Karpinets, T.V.; Stingo, F.C.; Baladandayuthapani, V.; Tetzlaff, M.T.; et al. Novel algorithmic approach predicts tumor mutation load and correlates with immunotherapy clinical outcomes using a defined gene mutation set. BMC Med. 2016, 14, 168. [CrossRef]

81. US Food and Drug Administration. FDA Approves Pembrolizumab for Adults and Children With TMB-H Solid Tumors; US Food and Drug Administration: Silver Spring, MD, USA, 2020.

82. Yarchoan, M.; Hopkins, A.; Jaffee, E.M. Tumor mutational burden and response rate to PD-1 inhibition. N. Engl. J. Med. 2017, 377, 2500-2501. [CrossRef]

83. Lee, V.; Murphy, A.; Le, D.T.; Diaz, L.A. Mismatch repair deficiency and response to immune checkpoint blockade. Oncologist 2016, 21, 1200-1211. [CrossRef]

84. Cortes-Ciriano, I.; Lee, S.; Park, W.-Y.; Kim, T.-M.; Park, P.J. A molecular portrait of microsatellite instability across multiple cancers. Nat. Commun. 2017, 8, 15180. [CrossRef] 
85. US Food and Drug Administration. FDA Grants Accelerated Approval to Pembrolizumab for First Tissue/Site Agnostic Indication; US Food and Drug Administration: Silver Spring, MD, USA, 2017.

86. Thomas, N.E.; Busam, K.J.; From, L.; Kricker, A.; Armstrong, B.K.; Anton-Culver, H.; Gruber, S.B.; Gallagher, R.P.; Zanetti, R.; Rosso, S.; et al. Tumor-infiltrating lymphocyte grade in primary melanomas is independently associated with melanoma-specific survival in the population-based genes, environment and melanoma study. J. Clin. Oncol. 2013, 31, 4252-4259. [CrossRef]

87. Brambilla, E.; Le Teuff, G.; Marguet, S.; Lantuejoul, S.; Dunant, A.; Graziano, S.; Pirker, R.; Douillard, J.-Y.; Le Chevalier, T.; Filipits, M.; et al. Prognostic effect of tumor lymphocytic infiltration in resectable non-small-cell lung cancer. J. Clin. Oncol. 2016, 34, 1223-1230. [CrossRef] [PubMed]

88. Gao, G.; Wang, Z.; Qu, X.; Zhang, Z. Prognostic value of tumor-infiltrating lymphocytes in patients with triple-negative breast cancer: A systematic review and meta-analysis. BMC Cancer 2020, 20, 179. [CrossRef] [PubMed]

89. Tumeh, P.C.; Harview, C.L.; Yearley, J.H.; Shintaku, I.P.; Taylor, E.J.M.; Robert, L.; Chmielowski, B.; Spasic, M.; Henry, G.; Ciobanu, V.; et al. PD-1 blockade induces responses by inhibiting adaptive immune resistance. Nature 2014, 515, 568-571. [CrossRef] [PubMed]

90. Herbst, R.S.; Soria, J.-C.; Kowanetz, M.; Fine, G.D.; Hamid, O.; Gordon, M.S.; Sosman, J.A.; McDermott, D.F.; Powderly, J.D.; Gettinger, S.N.; et al. Predictive correlates of response to the anti-PD-L1 antibody MPDL3280A in cancer patients. Nature 2014, 515, 563-567. [CrossRef]

91. Galon, J.; Mlecnik, B.; Bindea, G.; Angell, H.K.; Berger, A.; Lagorce, C.; Lugli, A.; Zlobec, I.; Hartmann, A.; Bifulco, C.; et al. Towards the introduction of the 'Immunoscore' in the classification of malignant tumours. J. Pathol. 2014, 232, 199-209. [CrossRef] [PubMed]

92. Galon, J.; Lanzi, A. Immunoscore and its introduction in clinical practice. Q. J. Nucl. Med. Mol. Imaging 2020, 64, 152-161. [CrossRef] [PubMed]

93. Weber, J.S.; D'Angelo, S.P.; Minor, D.; Hodi, F.S.; Gutzmer, R.; Neyns, B.; Hoeller, C.; Khushalani, N.I.; Miller, W.H.; Lao, C.D.; et al. Nivolumab versus chemotherapy in patients with advanced melanoma who progressed after anti-CTLA-4 treatment (CheckMate 037): A randomised, controlled, open-label, phase 3 trial. Lancet Oncol. 2015, 16, 375-384. [CrossRef]

94. Robert, C.; Ribas, A.; Wolchok, J.D.; Hodi, F.S.; Hamid, O.; Kefford, R.; Weber, J.S.; Joshua, A.M.; Hwu, W.-J.; Gangadhar, T.C.; et al. Anti-programmed-death-receptor-1 treatment with pembrolizumab in ipilimumab-refractory advanced melanoma: A randomised dose-comparison cohort of a phase 1 trial. Lancet 2014, 384, 1109-1117. [CrossRef]

95. Mok, T.S.K.; Wu, Y.-L.; Kudaba, I.; Kowalski, D.M.; Cho, B.C.; Turna, H.Z.; Castro, G.; Srimuninnimit, V.; Laktionov, K.K.; Bondarenko, I.; et al. Pembrolizumab versus chemotherapy for previously untreated, PD-L1-expressing, locally advanced or metastatic non-small-cell lung cancer (KEYNOTE-042): A randomised, open-label, controlled, phase 3 trial. Lancet 2019, 393, 1819-1830. [CrossRef]

96. Herbst, R.S.; Baas, P.; Kim, D.-W.; Felip, E.; Pérez-Gracia, J.L.; Han, J.-Y.; Molina, J.; Kim, J.-H.; Arvis, C.D.; Ahn, M.-J.; et al. Pembrolizumab versus docetaxel for previously treated, PD-L1-positive, advanced non-small-cell lung cancer (KEYNOTE-010): A randomised controlled trial. Lancet 2016, 387, 1540-1550. [CrossRef]

97. Langer, C.J.; Gadgeel, S.M.; Borghaei, H.; Papadimitrakopoulou, V.A.; Patnaik, A.; Powell, S.F.; Gentzler, R.D.; Martins, R.G.; Stevenson, J.P.; Jalal, S.I.; et al. Carboplatin and pemetrexed with or without pembrolizumab for advanced, non-squamous non-small-cell lung cancer: A randomised, phase 2 cohort of the open-label KEYNOTE-021 study. Lancet Oncol. 2016, 17, 1497-1508. [CrossRef]

98. Paz-Ares, L.; Luft, A.; Vicente, D.; Tafreshi, A.; Gümüş, M.; Mazières, J.; Hermes, B.; Çay Şenler, F.; Csőszi, T.; Fülöp, A.; et al. Pembrolizumab plus chemotherapy for squamous non-small-cell lung cancer. N. Engl. J. Med. 2018, 379, 2040-2051. [CrossRef]

99. Reck, M.; Rodríguez-Abreu, D.; Robinson, A.G.; Hui, R.; Csőszi, T.; Fülöp, A.; Gottfried, M.; Peled, N.; Tafreshi, A.; Cuffe, S.; et al Updated analysis of KEYNOTE-024: Pembrolizumab versus platinum-based chemotherapy for advanced non-small-cell lung cancer with PD-11 tumor proportion score of 50\% or greater. J. Clin. Oncol. 2019, 37, 537-546. [CrossRef] [PubMed]

100. Von Pawel, J.; Bordoni, R.; Satouchi, M.; Fehrenbacher, L.; Cobo, M.; Han, J.Y.; Hida, T.; Moro-Sibilot, D.; Conkling, P.; Gandara, D.R.; et al. Long-term survival in patients with advanced non-small-cell lung cancer treated with atezolizumab versus docetaxel: Results from the randomised phase III OAK study. Eur. J. Cancer 2019, 107, 124-132. [CrossRef]

101. Reck, M.; Mok, T.S.K.; Nishio, M.; Jotte, R.M.; Cappuzzo, F.; Orlandi, F.; Stroyakovskiy, D.; Nogami, N.; Rodríguez-Abreu, D.; Moro-Sibilot, D.; et al. Atezolizumab plus bevacizumab and chemotherapy in non-small-cell lung cancer (IMpower150): Key subgroup analyses of patients with EGFR mutations or baseline liver metastases in a randomised, open-label phase 3 trial. Lancet Respir. Med. 2019, 7, 387-401. [CrossRef]

102. Borghaei, H.; Paz-Ares, L.; Horn, L.; Spigel, D.R.; Steins, M.; Ready, N.E.; Chow, L.Q.; Vokes, E.E.; Felip, E.; Holgado, E.; et al. Nivolumab versus docetaxel in advanced nonsquamous non-small-cell lung cancer. N. Engl. J. Med. 2015, 373, 1627-1639. [CrossRef] [PubMed]

103. Antonia, S.J.; Villegas, A.; Daniel, D.; Vicente, D.; Murakami, S.; Hui, R.; Kurata, T.; Chiappori, A.; Lee, K.H.; De Wit, M.; et al. Overall survival with durvalumab after chemoradiotherapy in stage III NSCLC. N. Engl. J. Med. 2018, 379, 2342-2350. [CrossRef]

104. Horn, L.; Mansfield, A.S.; Szczęsna, A.; Havel, L.; Krzakowski, M.; Hochmair, M.J.; Huemer, F.; Losonczy, G.; Johnson, M.L.; Nishio, M.; et al. First-line atezolizumab plus chemotherapy in extensive-stage small-cell lung cancer. N. Engl. J. Med. 2018, 379, 2220-2229. [CrossRef] 
105. Paz-Ares, L.; Dvorkin, M.; Chen, Y.; Reinmuth, N.; Hotta, K.; Trukhin, D.; Statsenko, G.; Hochmair, M.J.; Özgüroğlu, M.; Ji, J.H.; et al. Durvalumab plus platinum-etoposide versus platinum-etoposide in first-line treatment of extensive-stage small-cell lung cancer (CASPIAN): A randomised, controlled, open-label, phase 3 trial. Lancet 2019, 394, 1929-1939. [CrossRef]

106. Antonia, S.J.; López-Martin, J.A.; Bendell, J.; Ott, P.A.; Taylor, M.; Eder, J.P.; Jäger, D.; Pietanza, M.C.; Le, D.T.; de Braud, F.; et al. Nivolumab alone and nivolumab plus ipilimumab in recurrent small-cell lung cancer (CheckMate 032): A multicentre, open-label, phase 1/2 trial. Lancet Oncol. 2016, 17, 883-895. [CrossRef]

107. Schmid, P.; Adams, S.; Rugo, H.S.; Schneeweiss, A.; Barrios, C.H.; Iwata, H.; Diéras, V.; Hegg, R.; Im, S.-A.; Shaw Wright, G.; et al. Atezolizumab and Nab-Paclitaxel in advanced triple-negative breast cancer. N. Engl. J. Med. 2018, 379, 2108-2121. [CrossRef]

108. Weber, J.; Mandala, M.; Del Vecchio, M.; Gogas, H.J.; Arance, A.M.; Cowey, C.L.; Dalle, S.; Schenker, M.; Chiarion-Sileni, V.; Marquez-Rodas, I.; et al. Adjuvant nivolumab versus ipilimumab in resected stage III or IV melanoma. N. Engl. J. Med. 2017, 377, 1824-1835. [CrossRef]

109. Eggermont, A.M.M.; Chiarion-sileni, V.; Grob, J.-J.; Dummer, R.; Wolchok, J.D.; Schmidt, H.; Hamid, O.; Robert, C.; Ascierto, P.A.; Richards, J.M.; et al. Prolonged survival in stage III melanoma with ipilimumab adjuvant therapy. N. Engl. J. Med. 2016, 375, 1845-1855. [CrossRef] [PubMed]

110. Robert, C.; Schachter, J.; Long, G.V.; Arance, A.; Grob, J.J.; Mortier, L.; Daud, A.; Carlino, M.S.; McNeil, C.; Lotem, M.; et al. Pembrolizumab versus ipilimumab in advanced melanoma. N. Engl. J. Med. 2015, 372, 2521-2532. [CrossRef]

111. Robert, C.; Long, G.V.; Brady, B.; Dutriaux, C.; Maio, M.; Mortier, L.; Hassel, J.C.; Rutkowski, P.; McNeil, C.; Kalinka-Warzocha, E.; et al. Nivolumab in previously untreated melanoma without BRAF mutation. N. Engl. J. Med. 2015. [CrossRef] [PubMed]

112. Ribas, A.; Puzanov, I.; Dummer, R.; Schadendorf, D.; Hamid, O.; Robert, C.; Hodi, F.S.; Schachter, J.; Pavlick, A.C.; Lewis, K.D.; et al. Pembrolizumab versus investigator-choice chemotherapy for ipilimumab-refractory melanoma (KEYNOTE-002): A randomised, controlled, phase 2 trial. Lancet Oncol. 2015, 16, 908-918. [CrossRef]

113. Nghiem, P.; Bhatia, S.; Lipson, E.J.; Sharfman, W.H.; Kudchadkar, R.R.; Brohl, A.S.; Friedlander, P.A.; Daud, A.; Kluger, H.M.; Reddy, S.A.; et al. Durable tumor regression and overall survival in patients with advanced merkel cell carcinoma receiving pembrolizumab as first-line therapy. J. Clin. Oncol. 2019, 37, 693-702. [CrossRef]

114. Kaufman, H.L.; Russell, J.; Hamid, O.; Bhatia, S.; Terheyden, P.; D’Angelo, S.P.; Shih, K.C.; Lebbé, C.; Linette, G.P.; Milella, M.; et al. Avelumab in patients with chemotherapy-refractory metastatic Merkel cell carcinoma: A multicentre, single-group, open-label, phase 2 trial. Lancet Oncol. 2016, 17, 1374-1385. [CrossRef]

115. Migden, M.R.; Rischin, D.; Schmults, C.D.; Guminski, A.; Hauschild, A.; Lewis, K.D.; Chung, C.H.; Hernandez-Aya, L.; Lim, A.M.; Chang, A.L.S.; et al. PD-1 blockade with cemiplimab in advanced cutaneous squamous-cell carcinoma. N. Engl. J. Med. 2018, 379, 341-351. [CrossRef] [PubMed]

116. Motzer, R.J.; Tannir, N.M.; McDermott, D.F.; Arén Frontera, O.; Melichar, B.; Choueiri, T.K.; Plimack, E.R.; Barthélémy, P.; Porta, C.; George, S.; et al. Nivolumab plus ipilimumab versus sunitinib in advanced renal-cell carcinoma. N. Engl. J. Med. 2018, 378, 1277-1290. [CrossRef]

117. Motzer, R.J.; Penkov, K.; Haanen, J.; Rini, B.; Albiges, L.; Campbell, M.T.; Venugopal, B.; Kollmannsberger, C.; Negrier, S.; Uemura, M.; et al. Avelumab plus axitinib versus sunitinib for advanced renal-cell carcinoma. N. Engl. J. Med. 2019, 380, $1103-1115$. [CrossRef] [PubMed]

118. Rini, B.I.; Plimack, E.R.; Stus, V.; Gafanov, R.; Hawkins, R.; Nosov, D.; Pouliot, F.; Alekseev, B.; Soulières, D.; Melichar, B.; et al. Pembrolizumab plus axitinib versus sunitinib for advanced renal-cell carcinoma. N. Engl. J. Med. 2019, 380, 1116-1127. [CrossRef]

119. Motzer, R.J.; Escudier, B.; McDermott, D.F.; George, S.; Hammers, H.J.; Srinivas, S.; Tykodi, S.S.; Sosman, J.A.; Procopio, G.; Plimack, E.R.; et al. Nivolumab versus everolimus in advanced renal-cell carcinoma. N. Engl. J. Med. 2015, 373, $1803-1813$. [CrossRef] [PubMed]

120. Necchi, A.; Joseph, R.W.; Loriot, Y.; Hoffman-Censits, J.; Perez-Gracia, J.L.; Petrylak, D.P.; Derleth, C.L.; Tayama, D.; Zhu, Q.; Ding, B.; et al. Atezolizumab in platinum-treated locally advanced or metastatic urothelial carcinoma: Post-progression outcomes from the phase II IMvigor210 study. Ann. Oncol. 2017, 28, 3044-3050. [CrossRef] [PubMed]

121. Balar, A.V.; Castellano, D.; O’Donnell, P.H.; Grivas, P.; Vuky, J.; Powles, T.; Plimack, E.R.; Hahn, N.M.; de Wit, R.; Pang, L.; et al. First-line pembrolizumab in cisplatin-ineligible patients with locally advanced and unresectable or metastatic urothelial cancer (KEYNOTE-052): A multicentre, single-arm, phase 2 study. Lancet Oncol. 2017, 18, 1483-1492. [CrossRef]

122. Sharma, P.; Retz, M.; Siefker-Radtke, A.; Baron, A.; Necchi, A.; Bedke, J.; Plimack, E.R.; Vaena, D.; Grimm, M.-O.; Bracarda, S.; et al. Nivolumab in metastatic urothelial carcinoma after platinum therapy (CheckMate 275): A multicentre, single-arm, phase 2 trial. Lancet Oncol. 2017, 18, 312-322. [CrossRef]

123. Massard, C.; Gordon, M.S.; Sharma, S.; Rafii, S.; Wainberg, Z.A.; Luke, J.; Curiel, T.J.; Colon-Otero, G.; Hamid, O.; Sanborn, R.E.; et al. Safety and efficacy of durvalumab (MEDI4736), an anti-programmed cell death ligand-1 immune checkpoint inhibitor, in patients with advanced urothelial bladder cancer. J. Clin. Oncol. 2016, 34, 3119-3125. [CrossRef]

124. Keilholz, U.; Mehnert, J.M.; Bauer, S.; Bourgeois, H.; Patel, M.R.; Gravenor, D.; Nemunaitis, J.J.; Taylor, M.H.; Wyrwicz, L.; Lee, K.-W.; et al. Avelumab in patients with previously treated metastatic melanoma: Phase $1 \mathrm{~b}$ results from the JAVELIN solid tumor trial. J. Immunother. Cancer 2019, 7, 12. [CrossRef] [PubMed]

125. Bellmunt, J.; De Wit, R.; Vaughn, D.J.; Fradet, Y.; Lee, J.-L.; Fong, L.; Vogelzang, N.J.; Climent, M.A.; Petrylak, D.P.; Choueiri, T.K.; et al. Pembrolizumab as second-line therapy for advanced urothelial carcinoma. N. Engl. J. Med. 2017, 376, 1015-1026. [CrossRef] [PubMed] 
126. Chung, H.C.; Ros, W.; Delord, J.P.; Perets, R.; Italiano, A.; Shapira-Frommer, R.; Manzuk, L.; Piha-Paul, S.A.; Xu, L.; Zeigenfuss, S.; et al. Efficacy and safety of pembrolizumab in previously treated advanced cervical cancer: Results from the phase II KEYNOTE-158 study. J. Clin. Oncol. 2019, 37, 1470-1478. [CrossRef] [PubMed]

127. El-Khoueiry, A.B.; Sangro, B.; Yau, T.; Crocenzi, T.S.; Kudo, M.; Hsu, C.; Kim, T.-Y.; Choo, S.-P.; Trojan, J.; Welling, T.H.; et al. Nivolumab in patients with advanced hepatocellular carcinoma (CheckMate 040): An open-label, non-comparative, phase $1 / 2$ dose escalation and expansion trial. Lancet 2017, 389, 2492-2502. [CrossRef]

128. Zhu, A.X.; Finn, R.S.; Edeline, J.; Cattan, S.; Ogasawara, S.; Palmer, D.; Verslype, C.; Zagonel, V.; Fartoux, L.; Vogel, A.; et al. Pembrolizumab in patients with advanced hepatocellular carcinoma previously treated with sorafenib (KEYNOTE-224): A non-randomised, open-label phase 2 trial. Lancet Oncol. 2018, 19, 940-952. [CrossRef]

129. Kojima, T.; Muro, K.; Francois, E.; Hsu, C.-H.; Moriwaki, T.; Kim, S.-B.; Lee, S.-H.; Bennouna, J.; Kato, K.; Lin, S.; et al. Pembrolizumab versus chemotherapy as second-line therapy for advanced esophageal cancer: Phase III KEYNOTE-181 study. $J$. Clin. Oncol. 2019, 37, 2. [CrossRef]

130. Fuchs, C.S.; Doi, T.; Jang, R.W.; Muro, K.; Satoh, T.; Machado, M.; Sun, W.; Jalal, S.I.; Shah, M.A.; Metges, J.-P.; et al. Safety and efficacy of pembrolizumab monotherapy in patients with previously treated advanced gastric and gastroesophageal junction cancer. JAMA Oncol. 2018, 4, e180013. [CrossRef] [PubMed]

131. Marabelle, A.; Le, D.T.; Ascierto, P.A.; Di Giacomo, A.M.; de Jesus-Acosta, A.; Delord, J.P.; Geva, R.; Gottfried, M.; Penel, N.; Hansen, A.R.; et al. Efficacy of pembrolizumab in patients with noncolorectal high microsatellite instability/ mismatch repair-deficient cancer: Results from the phase II KEYNOTE-158 study. J. Clin. Oncol. 2020. [CrossRef] [PubMed]

132. Rischin, D.; Harrington, K.J.; Greil, R.; Soulieres, D.; Tahara, M.; de Castro, G.; Psyrri, A.; Baste, N.; Neupane, P.C.; Bratland, A.; et al. Protocol-specified final analysis of the phase 3 KEYNOTE-048 trial of pembrolizumab (pembro) as first-line therapy for recurrent/metastatic head and neck squamous cell carcinoma (R/M HNSCC). J. Clin. Oncol. 2019, 37, 6000. [CrossRef]

133. Seiwert, T.Y.; Burtness, B.; Mehra, R.; Weiss, J.; Berger, R.; Eder, J.P.; Heath, K.; McClanahan, T.; Lunceford, J.; Gause, C.; et al. Safety and clinical activity of pembrolizumab for treatment of recurrent or metastatic squamous cell carcinoma of the head and neck (KEYNOTE-012): An open-label, multicentre, phase 1b trial. Lancet Oncol. 2016, 17, 956-965. [CrossRef]

134. Ferris, R.L.; Blumenschein, G.; Fayette, J.; Guigay, J.; Colevas, A.D.; Licitra, L.; Harrington, K.; Kasper, S.; Vokes, E.E.; Even, C.; et al. Nivolumab for recurrent squamous-cell carcinoma of the head and neck. N. Engl. J. Med. 2016, 375, 1856-1867. [CrossRef]

135. Chen, R.; Zinzani, P.L.; Fanale, M.A.; Armand, P.; Johnson, N.A.; Brice, P.; Radford, J.; Ribrag, V.; Molin, D.; Vassilakopoulos, T.P.; et al. Phase II study of the efficacy and safety of pembrolizumab for relapsed/refractory classic Hodgkin Lymphoma. J. Clin. Oncol. 2017, 35, 2125-2132. [CrossRef]

136. Zinzani, P.; Thieblemont, C.; Melnichenko, V.; Osmanov, D.; Bouabdallah, K.; Walewski, J.; Majlis, A.; Fogliatto, L.; Caballero Barrigón, M.D.; Christian, B.; et al. Efficacy and safety of pembrolizumab in relapsed/refractory primary mediastinal large B-cell lymphoma (rrPMBCL): Interim analysis of the KEYNOTE-170 phase 2 trial. Hematol. Oncol. 2017, 35, 62-63. [CrossRef]

137. Andorsky, D.J.; Yamada, R.E.; Said, J.; Pinkus, G.S.; Betting, D.J.; Timmerman, J.M. Programmed death ligand 1 is expressed by non-Hodgkin lymphomas and inhibits the activity of tumor-associated T cells. Clin. Cancer Res. 2011, 17, 4232-4244. [CrossRef]

138. Chen, X.; Liu, S.; Wang, L.; Zhang, W.; Ji, Y.; Ma, X. Clinical significance of B7-H1 (PD-L1) expression in human acute leukemia. Cancer Biol. Ther. 2008, 7, 622-627. [CrossRef] [PubMed]

139. Yao, Y.; Tao, R.; Wang, X.; Wang, Y.; Mao, Y.; Zhou, L.F. B7-H1 is correlated with malignancy-grade gliomas but is not expressed exclusively on tumor stem-like cells. Neuro. Oncol. 2009, 11, 757-766. [CrossRef]

140. Kabir, T.F.; Chauhan, A.; Anthony, L.; Hildebrandt, G.C. Immune checkpoint inhibitors in pediatric solid tumors: Status in 2018. Ochsner J. 2018, 18, 370-376. [CrossRef]

141. Chowdhury, F.; Dunn, S.; Mitchell, S.; Mellows, T.; Ashton-Key, M.; Gray, J.C. PD-L1 and CD8 ${ }^{+}$PD1 ${ }^{+}$lymphocytes exist as targets in the pediatric tumor microenvironment for immunomodulatory therapy. Oncoimmunology 2015, 4, e1029701. [CrossRef]

142. Wagner, L.M.; Adams, V.R. Targeting the PD-1 pathway in pediatric solid tumors and brain tumors. Onco. Targets. Ther. 2017, 10, 2097-2106. [CrossRef] [PubMed]

143. Park, J.A.; Cheung, N.K.V. Targets and antibody formats for immunotherapy of neuroblastoma. J. Clin. Oncol. 2020, 38, 1836-1848. [CrossRef]

144. Davis, K.L.; Fox, E.; Merchant, M.S.; Reid, J.M.; Kudgus, R.A.; Liu, X.; Minard, C.G.; Voss, S.; Berg, S.L.; Weigel, B.J.; et al. Nivolumab in children and young adults with relapsed or refractory solid tumours or lymphoma (ADVL1412): A multicentre, open-label, single-arm, phase 1-2 trial. Lancet Oncol. 2020, 21, 541-550. [CrossRef]

145. Hutzen, B.; Paudel, S.N.; Naeimi Kararoudi, M.; Cassady, K.A.; Lee, D.A.; Cripe, T.P. Immunotherapies for pediatric cancer: Current landscape and future perspectives. Cancer Metastasis Rev. 2019, 38, 573-594. [CrossRef]

146. Azzaoui, I.; Uhel, F.; Rossille, D.; Pangault, C.; Dulong, J.; Le Priol, J.; Lamy, T.; Houot, R.; Le Gouill, S.; Cartron, G.; et al. T-cell defect in diffuse large B-cell lymphomas involves expansion of myeloid-derived suppressor cells. Blood 2016, 128, 1081-1092. [CrossRef] [PubMed]

147. Lu, C.; Redd, P.S.; Lee, J.R.; Savage, N.; Liu, K. The expression profiles and regulation of PD-L1 in tumor-induced myeloid-derived suppressor cells. Oncoimmunology 2016, 5. [CrossRef] [PubMed]

148. Iwata, T.; Kondo, Y.; Kimura, O.; Morosawa, T.; Fujisaka, Y.; Umetsu, T.; Kogure, T.; Inoue, J.; Nakagome, Y.; Shimosegawa, T. PD-L1+ MDSCs are increased in HCC patients and induced by soluble factor in the tumor microenvironment. Sci. Rep. 2016, 6 . [CrossRef] [PubMed] 
149. Stiff, A.; Trikha, P.; Mundy-Bosse, B.; McMichael, E.; Mace, T.A.; Benner, B.; Kendra, K.; Campbell, A.; Gautam, S.; Abood, D.; et al. Nitric oxide production by myeloid-derived suppressor cells plays a role in impairing Fc receptor-mediated natural killer cell function. Clin. Cancer Res. 2018, 24, 1891-1904. [CrossRef]

150. Tumino, N.; Di Pace, A.L.; Besi, F.; Quatrini, L.; Vacca, P.; Moretta, L. Interaction between MDSC and NK cells in solid and hematological malignancies: Impact on HSCT. Front. Immunol. 2021, 12, 638841. [CrossRef]

151. Locati, M.; Curtale, G.; Mantovani, A. Diversity, mechanisms, and significance of macrophage plasticity. Annu. Rev. Pathol. Mech. Dis. 2020, 15, 123-147. [CrossRef] 